tom SPECT 像で指摘していた。

演者らはう pixel の移動が限界と考えておられるようだが，その

臨床とのずれもぜひ知りたいところである。

核医学検査の主流が動態機能解析にある今, 本研究は収集デー夕 を救えるか否かに結び付くもので，しかもその原因となるものであ る．今後ぜひ簡便なる補正法へ発展されることをお願いしたい，

以上,第 4 から第 7 席はいずれも維密な解析ときめの細かい考察 がなされており，核医学諮療に取り組んで㧍られる日頃の情熱は言 うに及ばず，姿勢や考え方までうかがうことのできた素晴しい演題 であった。

\section{MRI Angio Coil}

座長 遊佐 烈（福島県立医科大学附属病院）

8.MTCを応用したMR angiography一短かいTRでの効果に ついてー

太田西ノ内病院

○新里昌一・佐竹正規・菅野和之・富塚光夫・藤田悠治 佐藤善二

〔目的〕MTCに関しては幾多の報告があるが，付加パルスによ り TRが延び険查時間が長くなる，今回，短かい TRでの効果につ いて比較検討したので報告する。

〔方法〕MTCピッチ 9 mesec，TR 38に短縮してMRAを撮 像。寒天及びボランティアにて, MTC出力を 0 から 100 まで変化さ せ効果を比較検討した。

【結果及び考察〕寒天の信号は，出力に伴い低下した。脳実質も 選択的に抑制された。ピッチを短縮しても，出力を最大にすること で血管の信号が相対的に多少向上した。 MTCは, ピッチ・TRが長 いと画質向上の効果が大きくなる。だが，検査時間が長くなる割に は臨床的な効果は少ないので，目的に合わせた使用が望まれる。

9. 高速グラジェントェコー法による肺の MR アンギオグラフィ

\section{仙台市立病院}

高橋規之・小林裕一・藤 泰・岩城賢郎・佐藤 護 東北大学医学部附属病院

斎 政博・梁川 功・佐々木正寿

Turbo-FLASH を使用し，IRパルス部のRF 出力電圧を 0 ボル トにすることで，通常の FLASH より高速化することができた。本 法により，TOF 効果による2D 及び 3D の肺の MRAを試みた。2 次元撮影においては，一回呼吸停止下に心電同期を用い，コロナル 像12枚を得て，MIPする．3次元においては，サジタルにスラブを 設定し，呼吸同期を用い片肺を得る。撮像時間，約 5 分. 2 次元に おいては，心電同期より，任意の心時相で撮像可能. 3 次元では, 呼吸同期により，末梢部の描出能が向上した。（5次分枝まで）

使用装置：SIEMEN IMPACT, VISION

コイル：CPボティアレイコイル

\section{0．乳房専用コイルの使用経験}

山形県立中央度院

○永沢賢司・奈良崎祐逸・逸見弘之・小林英明・青柳忠温 岩田紘一

山形県米沢保健所 森田健一

〔目的〕当院では, 乳房専用コイルを用いて検査を行っている が，その使用状況及び結果について報告する。
〔方法〕 (1) T1WI Axial (SE) (2) T1WI Sagittal (SE) (3) Dynamic MRI (FSE) (4) T1WI Axial (SE) Enhance (5) T1WI Sagittal (SE) Enhance 撮像後, サブトラクション像と時間一信号 強度曲線を作成する。

〔結果及び考察〕撮影ポジショニングが比較的容易で, S/N比 の良好な画像が得られる。腹卧位でのポジショニングのため, 呼吸 の影響が少ない，腫留の境界が判然としない症例においても，サブ トラクション像により病変の描出と浸潤範囲が把握できる.サブト ラクション像で注，位置ずれによるアーチファクトを生じやすい． 11. 骨盤部 MRI 検査における BODY ARRAY COILの有用性 弘前大学医学部附属病院

○谷雄彦・过 敏朗・金澤隆太郎・楢木 瞈・传藤幸夫 安倍勝美

Body Array Coil の有用性について, Body Coil との比較をファ ントム実験及び，臨床 Imageにて行った。その結果, Body Array Coil の使用は，診断に十分なSNR を保ったまま，Body Coil では 困難とされていた，小FOV，薄い Thickness，小 Matrix Size の スキャンパラメータの選択が可能となり,より高分解能画像が検査 時間の大幅な延長はなく, 特に呼吸動の少ない骨盤領域では, より 質の高いMRI 検查がなされるようになったと考える。

しかし，コイル装着による患者への負担，スループットへの影 響，コイル近傍表面が高信号等，今後，他部位への応用を含め，検 討を重ねていきたい.

\section{座長集約}

当セッションは MR アンギオに関するもの 2 題，コイルの使用 に関するもの 2 題, 合計 4 題の臨床報告である. 演題 8 , 太田西） 内の新里らは，頭部での MTC 画像に，装置の最少 TR を固定し， 最良のパラメータを検討している，MTC 画像に関する発表も多く なってきている中，会場よりSAR (比吸収率)に関する質問も出さ れた. 他の部会等でも同様の質問が頻回に出されるが, 新しいシー ケンスでのリスクに対する疑問は当然の事である.今回この質問に 対しての答は得られなかったが, 常にこの安全基準值を越えない様 に確かめることは, 新しいシーケンスを試みる際の最低限の義務で あろう。

演題 9 , 仙台市立の高橋らは, TURBO-FLASH の IR パルス部 RF 出力を 0 とし，通常の FLASH より高速化したとしているが， IR 0 とした事で，脂肪または水の選択的画像化が出来なくなり， その結果として，脂肪が高く見えてこないかとの質問に，肺に対し ては影響は無いとの答であった。

特異的な使用法は，撮影部位抢よび適応症例に対する配慮が必要 である事が示唆され有用な報告であった。

演題10，山形県立中央の永沢らは，乳房コイルの使用経験に関す る発表で, 東北大の梁抵より, 胸壁近くの腫痬及び, 腋窝りンパ 節の確認の有無に対する質問があり，意図的に行わなくてもかなり の範囲が描出されるとの答であった，又，患者の位置ずれの問題を 提起されたが，他の施設よりの工夫や，適切なアドバイス等がでな かったのは非常に残念に思う。

演題11, 弘前大学の大谷らは, 骨盤部領域に対する Body Array Coil の有用性について, 従来の Body Coil 上り空間伃解能の向上 等が得られるとの事であった。東北大の梁川氏より，被写体の厚さ によるS/N，均一性の変化に対して質問があり，今回は検討を行っ ていないとの答であった，更にコイル近くの脂肪の強信号による呼 
吸性アーティファクトに対する質問に対しては，2回のアベレージ ングを行っているとの事であった。

\section{MRI 評価・他}

座長 梁川 功 (東北大学医学部附属病院)

12.MRIにおけるMTF およびウィナースペクトル測定一測定法 の検討一

NTT 東北病院 C大久敏弘

NTT 東北病院 伊藤道明

仙台赤十字病院 安彦 茂

東北大学医学部附属病院 佐々木清昭

MR 像のMTFおよびウィナースペクトル剆定法を検討した。ビ ニールチューブに水で希积したマグネビスト溶液を充填し，その横 断像を撮影し，得られた点像について2次元のフーリエ変換を行い MTFを求めた。均一性評価用球状ファントムの横断像より複数の 矩形領域をセグメントデータとして切り出し，フーリエ変换法によ クウィナースペクトルを求めた。結果として，1，MR像のMTF， ウィナースペクトルの剆定が可能になった，2．MTF 測定時のエ リアシングの影響は無視できず,その補正が必要だった.3。ウィナ 一スペクトルカーブの形状は, シーケンスの違いに因らずホワイト ノイズ様であった、4．従来の差分像からのノイズ評価法では，機種 固有の特異な不均一性を評価できなかった。

13. MRIにおけるウィナースペクトルの測定一機種間での比較一 仙台赤十字病院 三安彦 茂

NTT 東北病院 大久敏広・伊藤道明

東北大学医学部附属病院 估々木清昭

〔概要〕 Magnetom Vision 1.5 T, Magnetom Impact 1.0 T, Sierra 1.5T, Vectra Fast 0.5Tで, すべて均一評価ファントム 頭部用コイルを使ってシングルスライスで撮影し W.S 救めた。 また，W.S 值でファントムのピクセル值の平均值の 2 乗を割って $\mathrm{SNR}(\mathrm{u})^{2}$ を求め, 機種間の比較を行った。

〔まとめ) 1. 定常的に現れるノイズでは, $\operatorname{SNR}(u)^{2}$ による評価 が非常に有用であった。 2. SNR $(u)^{2}$ の比較の様に信号強度の差を 考慮して比較しなければならない.3．今回測定した1.5T2機種と 1.0T間の差はほとんどなかったが,この3機種と0.5Tの差注大き かったまた，同一機種間でも装置の状態によってはかなり差がで ることがわかった。

14. Morphographic Filter 処理画像の評価

青森整形外科クリニックこ西谷 衛

青森市民病院 稲葉孝典

青森県立中央病院 㝾藤兼也

MRI 画像の画質向上を目的に Morphographic Filter (以下, @MFとする。）処理画像が，当院のMRI 装置にも搭載されたので MRI 用 Phantom を撮像し(1)均一性(2) SNR (3)直線性上歪み(4)空 間分解能(5) CNRについて@MF 処理レベルを変化させた画像を 比較・検討し，蹦床画像についても険討した。@MF 処理は $1 〜 10$ 段階の処理レベルがあり，撮像計画の段階でも後処理でも設定可能 である。しかし，空間分解能が処理レベルにより低下するため、コ ントラストの低い病変や微細な部位が不鲜明になることがある。よ って, 対象藏器・撮像プロトコールに応じて@MF 强度の選択が必 要である。@MF 処理は均一性·SNR を改善することから微䋖なア ーチファクト・ノイズを軽減でき，臨床的に有効と考える。
15. 脂肪抑制画像（CHESS 法）による局所磁場不均一の測定 新渴大学医学部附属病院

こ大越幸和・柴木充朗・荒井 誠・長沢 弘

MRI では非常に高い静磁場均一性が求められ，また磁化率の異 なる物質や被写体の形状により局所磁場不均一が生じる。今回, CHESS 法による脂肪抑制パルスの周波数を変化できることを利 用し，静磁場均一性及びファントムの形状の変化やファントム中の 空気によって生じる局所磁場不均一の位置, 範囲, 周波数の変化の 測定を試みた。空気による不均一は静磁場に平行な方向では不均一 の範囲も広く，高周波数側に大きく変化した。また直交する方向で は空気の周囲に平行な方向上り比較的狭い範囲で周波数が低下し た。本法を用いることにより，静磁場均一性，局所磁場不均一の位 置や範围，周波数の変化を高い精度で剆定可能であった。

\section{座長集約}

本セッションは, MRI の画像評洒法に関する演題が 2 題，また画 像フィルターの評価, 局所磁場不均一の測定に関する演題の計 4 題 である。

演題12は, MR システムより外部のコンピュータに画像のディジ タルデータを取り出し，MRIにおけるMTF扔よびウィナースペ クトルの測定が可能になった，また，従来のNEMA 規格では評洒 できなかった装置固有の特性が把握でき，有用な手法であると報告 している.

演題13は, 異機種間について頭部用コイルにて均一評価用ファン トムを撮影し, ウィナースベクトルを求め画質の検討を行ってい る。この際, 翼機種間ではディジタル值が異なるため単純に比較で きず, ピクセル值の平均值の二乗をウィナースペクトル值で除した $\mathrm{SNR}(\mathrm{u})^{2}$ 求め比較している。白の結果, $1.5 \mathrm{~T}$ と $1.0 \mathrm{~T}$ 間の差はな く,0.5Tの装置では差が大きかったと報告している。磁場強度の違 いによるSNRの差は人体ではケミカルシフトの影響で少ないと 予想されるが，均一ファントムでは差がでてくるのではないか. MRI の函像評洒法に関する新しい手法であるが，簡便さやどの施 設でも測定可能(ディジタルデータを外部に取り出せるようにして おくとよい）とはいかず，今後の検討が必要であろう.

演題14は, Morphographic Filter 妈理を行った画像評価で, 均一 性, SNR の向上が見られたもの, 空間分解能が処理レベルに比例し て低下するため,コントラストの低い病変や微細な部位が不鲜明に なることがあるので，後処理が望ましいとしている。最近の MR 画 像は装置の向上に伴い, 256から512マトリックスへと高分解能の画 像が求めら机ているなか, 画像フィルターの使用にあたっては,十 分注意を払わなけ机ばならない。

演題15は，CHESS 法による脂肪抑制パルスの周波数を変化させ た画像をむとに3 次元表示し, 磁化率の異なる物質, 被写体の形状 による局所磁場不均一の範用，周波数が测定できたと報告してい る. CHESS 法による脂肪抑制画像は，わずか $3.5 \mathrm{ppm}$ しかない水 と脂肪の共鳴周波数差を利用し, 脂肪組織のみ選択的に励起させる ものである，従って効率的に分離するためには $1 \mathrm{ppm}$ 以下の高い 静磁場均一性が要求され，被写体による局所磁場不均一性も大きな 問題となる。演者らが想定した䫝部は特に脂肪抑制困難な部位であ り，測定結果とよく一致し，興味深い発表であった。

最近の MRI の発表の傾向として装置, 敢床応用の多いなか, 基 礎的な MRIの画像評価に関するものも大いに歓迎するものである。 今後のさらなる研鑽を期待したい。 